\title{
Dissociative identity disorder as a wide range of defense mechanisms in children with a history of early childhood trauma
}

\author{
Dysocjacyjne zaburzenie osobowości jako szeroki zakres mechanizmów obronnych \\ u dzieci z przebytą traumą we wczesnym dzieciństwie \\ Marta Cudzik ABDEF, Ewelina Soroka ADE https://orcid.org/0000-0001-6909-2749, \\ Marcin Olajossy DF https://orcid.org/0000-0002-1001-3185
}

II Department of Psychiatry and Psychiatric Rehabilitation, Medical University of Lublin

\begin{abstract}
Introduction: Dissociative identity disorder, also known as multiple personality disorder, involves simultaneous manifestation of multiple alternative personalities in one human body. The disorder is still a puzzle to contemporary researchers. In comparison to the United States, where the detection rate of this disorder is growing, in Poland, it is still a niche issue, unknown to many scientists and clinicians. Rather alarmingly, this situation has remained the same for many years now.

Objective: The aim of the present study is to draw attention to the adaptive character of dissociative identity disorder as a defense mechanism in children who have experienced extremely traumatic events in early childhood. The work also sets itself the task of disseminating knowledge about multiple personality disorder in the Polish scientific community, with the hope of encouraging wider research in this area in Poland.

Material and Methods: To investigate this issue, we searched articles available in the PubMed, Google Scholar, and Polish Medical Bibliography (Polska Bibliografia Lekarska) databases for the years 1960-2018. The following search terms were used: multiple personality, dissociative identity disorder, dissociative identity disorder and children. On the basis of a meta-analysis of the available literature, we offer a general characterization of the disorder, describe its symptomatology, present several theories of its etiology and conclude it through the prism of its adaptive function.

Results and Discussion: From the analysis of the gather data, we can conclude that multiple personality disorder can be a broad variant of the child's defense mechanisms against extreme, traumatic events from childhood, which they try to cope with by creating alter personalities. Abused children create other representations of the Self to be able to rid themselves of suffering, a process that is necessary for them to survive and further develop mentally and physically.

Conclusions: There is no doubt that Polish research on this disorder is much needed. It could provide more information on the epidemiology, diagnosis, and treatment of multiple personality. In addition, a better understanding of the issue might bring us closer to the understanding of how the human mind works.
\end{abstract}

Keywords: dissociative identity disorder, multiple personality, defense mechanisms

\section{Streszczenie}

Wstęp: Dysocjacyjne zaburzenie osobowości zwane też inaczej osobowością mnogą polega na jednoczesnym funkcjonowaniu w jednym organizmie ludzkim wielu alternatywnych osobowości. Zaburzenie to stanowi nadal zagadkę dla współczesnych badaczy zajmujących się tym zagadnieniem. W porównaniu do Stanów Zjednoczonych, gdzie rozpoznawalność tego zaburzenia ma tendencję wzrostową, w Polsce jest to nadal temat bardzo niszowy, a nawet nieznany dla wielu naukowców i klinicystów. Co więcej, sytuacja nie ulega zmianie od wielu lat.

Cel pracy: Celem pracy jest zwrócenie uwagi na adaptacyjny charakter dysocjacyjnego zaburzenia osobowości jako mechanizmu obronnego u dzieci, które przeszły we wczesnym dzieciństwie ekstremalnie traumatyczne zdarzenia. Praca ma również za zadanie rozpowszechnienie wiedzy na temat osobowości mnogiej w polskim środowisku naukowym, co może przyczynić się do szerszych badań na tym polu w Polsce.

Materiał i Metoda: Do zbadania tego zagadnienia wykorzystano dostępne artykuły z bazy PubMed, Google Scholar oraz Polskiej Bibliografii Lekarskiej pod hasłami: osobowość mnoga, dysocjacyjne zaburzenie osobowości, dysocjacyjne zaburzenie 
osobowości a dzieci w przedziale czasowym od 1960 do 2018 roku. Dzięki syntezie dostępnego piśmiennictwa dokonano ogólnej charakterystyki zaburzenia, opisu symptomatologii, przedstawienia kilku teorii jego powstawania po to aby następnie podsumować temat poprzez ujęcie osobowości mnogiej przez pryzmat jej adaptacyjnej funkcji.

Wyniki i Dyskusja: Z analizy zebranych danych wynika, że osobowość mnoga może być szerokim wariantem mechanizmów obronnych dziecka przed ekstremalnymi, traumatycznymi zdarzeniami z dzieciństwa, z którymi radzi sobie poprzez wytworzenie alternatywnych osobowości. Dziecko tworzy inne reprezentacje siebie, aby móc pozbyć się cierpienia, co jest niezbędne do przetrwania i dalszego rozwoju psychicznego jak i fizycznego.

Konkluzje: Nie ulega wątpliwości, że potrzebne są polskie badania na temat tego zaburzenia. Pozwoliłoby to uzyskać więcej informacji odnośnie epidemiologii, diagnostyki oraz leczenia osobowości mnogiej. Ponadto, lepsze zrozumienie tematu przybliżyłoby możliwość dokładniejszego poznania sposobu funkcjonowania ludzkiego umysłu.

Słowa kluczowe: dysocjacyjne zaburzenie osobowości, osobowość mnoga, osobowość wieloraka, mechanizmy obronne

\section{Introduction}

Dissociative identity disorder, due to its exceptional nature and difficulties in its identification, is rarely diagnosed in Poland. This disorder is rooted in the particular traumatic and repetitive events during childhood, while posttraumatic stress disorder (PTSD) is linked with tragic experiences in the later period of life. It is crucial, because children do not have suitable defense mechanisms, which allow to cope in such extreme conditions. Thus, they use imagination and fantasy, which allow them to survive with the help of dissociation and splitting.

\section{Objective}

This paper constitutes a review of the available literature on dissociative identity disorder as a wide range of defense mechanisms among children with unheard of trauma. Furthermore, this text is intended to draw attention of the scientific community to this disease and to begin a discussion of the Polish researches in this area.

\section{Material and Methods}

To conduct a meta-analysis we used available articles from the databases of PubMed Google Scholar and Polish Medical Bibliography under the following notions: multiple personality, dissociative identity disorder, dissociative identity disorder and children for the years 1960-2018.

In order to present the nature of that phenomenon as best as it is possible, the article was divided into the following sub-chapters:

1. Dissociative identity disorder - general characteristics.

2. Theories of etiology:

2.1 The psychoanalytical model;

2.2 The autohypnotic model;

2.3 The evolutionary model;

2.4 The attachment model;
3. Results and discussion - DID as a response to childhood trauma.

4. Conclusions and recommendations.

\section{Dissociative identity disorder - general characteristics.}

Dissociative identity disorder (DID), also known as multiple personality disorder, is a condition in which a person simultaneously has at least two or more independently existing personalities which alternately take full control over their behavior [1-3]. ICD-10 classifies multiple personality disorder under other dissociative (conversion) disorders F44.8 [4]. DSM-V places DID among dissociative disorders and defines it as the presence of two or more distinct personality states or an experience of possession with recurrent episodes of amnesia which cannot be explained as mere forgetfulness [5]. DID was first classified as a separate disease entity in DSM-III in 1980 in the section on dissociative disorders [2].

The prevalence of DID in adults is $1.5 \%$ in the United States [5] and from $0.5 \%$ to $2 \%$ in Canada. No statistical data are available for the Polish population [2]. The number of personalities usually oscillates between 3 and 5 but rarely exceeds 10, though there exist reports of cases with 25-30 different personalities. Women have on average 15 , and men 8 , separate alters $[1,2]$. The disorder affects three to nine times more women than men [2]. A typical person with dissociation is a woman between the age of 20 and 40 with a history of sexual abuse, incest, or other traumatic experiences suffered before the age of five. The patient may be excessively impressionable and prone to regressive and escape reactions $[1,2]$.

The multiple personalities of a DID patient can be divided into several categories: original personality (the one the patient was born with), alter personality, personality fragment (a single situation-related emotional state), and host personality (the dominant personality). The original personality usually does not know about the existence of the other personalities, although the latter are aware of the existence of the original personality and 
also often know about the presence of other personalities. More often than not, the host is the least disturbed personality. However, in some situations, one of the alters may be coping better and try to help the dominant personality, appearing when it is needed most. The emotional relationships among the different personalities depend on their role as personality categories [3].

A particularly interesting element of this disorder is the switching, i.e. the transition from one personality to another. It is a smooth transition, which is difficult to detect, especially if the patient is trying to conceal the disorder. An identity switch usually does not last longer than 5 minutes. It is accompanied by quick blinking or eye rolling followed by an empty, absent gaze. The heart and breathing rates change along with the body posture, facial expression and tone of voice. The alters may have their own ethnic or religious identity, gender, age, mood, affect, interests, habits, skills, and levels of activity [6]. A female patient reported the following experience: "I lie down, though I can do it seated. I concentrate with all my might, I clear my mind, I close access to all information, and then I express my wish for a given person to appear. However, I am not aware of what I am doing " [3].

DID patients experience a rich array of psychosomatic symptoms, which range from simple pains and dizziness through changes in handwriting style to suicide attempts and amnesia of different periods of life. There are also interpersonality differences in ECG recordings, hormonal profiles, cerebral blood flow, sensation of pain, or the course of the menstrual cycle. A case of a patient has been reported, who menstruated for the whole month because her alters had different period dates [2]. The most common psychopathologic symptoms were presented in Table 1.

Table 1. The most common psychopathologic symptoms of DID.

\begin{tabular}{|l|l|}
\hline Symptoms & Number of patients \\
\hline The existence "inside another person" & 92 \\
\hline Speaking voices & 89 \\
\hline Voices from the inside & 84 \\
\hline The feeling of being controlled by someone else & 83 \\
\hline Forgetfulness of childhood & 83 \\
\hline Referring to oneself in the plural & 75 \\
\hline Another surname of the person "inside" & 72 \\
\hline Amnesia of different periods of life & 69 \\
\hline Mentioning past "scenes" & 68 \\
\hline Forgotten life events being recounted by other people & 64 \\
\hline The feeling of unreality & 58 \\
\hline Failure to recognize people who profess to know the patient & 45 \\
\hline Announcement about patient's missing & 43 \\
\hline Waking up in an unknown place & 37 \\
\hline Unknown origin of some patients' things & 32 \\
\hline Having different handwriting styles & 28 \\
\hline
\end{tabular}

The disorder is diagnosed on the basis of standardized history-taking instruments: the Structured Clinical Interview for DSM-IV Dissociative DisordersRevised (SCID-DR) and scales: the Dissociative Experience Scale (DES), the Dissociative Disorders Interview Schedule (DDIS), the Somatoform Dissociation Questionnaire (SDQ- 20), the Childhood Trauma Questionnaire (CTQ) $[2,3,7]$.

DID is such an intriguing disorder that it has been portrayed in numerous literary and cinematic works. The book Sybil and the movie based on it tell the story of a patient with 16 personalities. The book found itself on the list of bestsellers. Another example is the movie The Three Faces of Eve based on a real story of a woman switching between three different personalities [2].

\section{Theories of etiology}

The etiology of DID is still unclear. It is hypothesized that the disease is a synthesis of many factors including inborn susceptibility, lack of social support, the influence of one's, especially one's family, and traumatic childhood events [2]. Traumatic childhood events are reported by $97 \%$ of multiple personality patients, $85 \%$ of which are experiences of sexual abuse. This is the most frequently 
reported type of abuse [1,6]. DID patients report having suffered severe, repetitive trauma at the hands of their own parents [8]. Other events that leave marks on the patients include incest (68\%), physical abuse (75\%), extreme negligence by caregivers (60\%), and death or presence at the death of a loved one (40\%). Usually, these events took place before the age of five $[1,2]$. Descriptions of more sophisticated child abuse practices are also not uncommon. Apart from various types of sexual practices, DID patients report having been abused physically by beating, kicking, burning with a clothes iron or matches, getting enemas, or being imprisoned in a basement, in a closet, or in a car trunk. There is a description of a case in which a person as a child was buried alive; the perpetrator left a breathing tube over her face, through which he urinated on her. The wide range of ways in which DID patients were maltreated as children include various forms of psychological trauma, such as constant denigration, humiliation, or forcing the child to watch their siblings being sexually abused. All these cases have the common feature of being particularly drastic and repetitive. Most researchers and clinicians dealing with this disorder agree that early childhood trauma is the main cause of the disease. This assumption has led scientists to formulating three models of formation of multiple personalities:

\section{1. the psychoanalytical model; \\ 2.2. the autohypnotic model; \\ 2.3. the evolutionary model [1];}

Worth noting is also Bowlby's daring hypothesis known as:

\section{4. the attachment model [9];}

All these models explain multiple personality disorder as an extreme way in which children try to cope with intolerable trauma, from which they cannot escape and against which they cannot defend themselves because of their physical and psychological immaturity.

\subsection{The psychoanalytic model}

This theory assumes that alters develop not as a result of a traumatic event as such, but due to defense mechanisms that are designed to protect the individual from dangerous content [1]. This model refers to Freud's views presented in his Studies on Hysteria [10]. According to this approach, two defense mechanisms play the most important role in the development of DID: splitting and dissociation.

Splitting is a natural psychological process, occurring mainly in infants, which allows them to separate good from evil. When a child is constantly subjected to traumatic experiences, they begin to overuse this mechanism even in non-threatening situations, which allows them to create two disparate worlds. This leads to the formation of new alter personalities which protect the child against the trauma [1,9].

Dissociation is an equally primitive defense mechanism that separates specific thoughts, memories or affects from the rest of the personality, causing them to function autonomously. Dissociation is guided by the primary process, which, by acting on the thoughts and feelings that are far away from the field of consciousness, subjects them to the action of its characteristic defense mechanisms: displacement, condensation and symbolization. According to Freud, the primary process, unlike the secondary process, has no cause-and-effect relations, opposites, and time, and is characterized by coexisting contradictions. Its task is to relieve the tension as quickly as possible by creating images of an object that satisfies the need. There is also no distinction between fantasy and reality, which seems to explain why alters do not find it contradictory to have a different sex, race or age than the original personality [1].

The psychoanalytical model, therefore, suggests that the development of DID requires two components: trauma and fantasy. This theory, however, is not perfect, because it does not explain all clinical symptoms [10]. What is more, it is claimed that not every person who can dissociate develops alter personalities [11]; though, on the other hand, patients suffering from DID have a significantly increased ability to dissociate, what suggests that this feature is a predisposing factor for developing this disorder [7].

\subsection{The autohypnotic model}

Like the psychoanalytic model, the autohypnotic paradigm assumes that dissociative patients escape from a traumatic event, but it proposes that they do so by engaging in autohypnosis, which then becomes a way to defend oneself against stressful situations in life $[1,9,10,12]$.

It has been proven that patients with DID are highly hypnotizable, although they often do not realize it [6]. Autohypnosis explains why DID patients often suffer from amnesia, develop other personalities, and are in possession of things they do not recognize as their own [10]. Bliss even goes as far as to say that multiple personality is a form of autohypnosis and that other symptoms of the disease, such as changes in breathing rate, irregular menstruation, and palpitations are manifestations of anxiety [12].

This model assumes that hypnosis is controlled dissociation, and dissociation, in turn, is a form of autohypnosis. Unfortunately, with time and with repeated traumas, autohypnosis becomes a solution to all kinds 
of distress. Overused, it interferes more and more with the individual's memory, sense of the Self, and normal ability to cope in the real world. The changes can range from short episodes of amnesia to the emergence of alter personalities which can take control of the patient's body.

Arguments in favor of this model include the high hypnotizability of the patients, the possibility of explaining many symptoms of the disorder in terms of autohypnosis, and the fact that hypnosis is a helpful method both in the diagnosis and treatment of multiple personality.

Criticism of this theory rests in the fact that it equates hypnotizability with susceptibility to dissociation. Some studies indicate that these processes are not synonymous, because although some people who are highly susceptible to dissociation are also susceptible to hypnosis, not all hypnotizable persons are able to dissociate [1].

\subsection{The developmental model}

Research shows that people with DID have a period of special sensitivity during which traumatic events can lead to the formation of a multiple personality. This period falls between the ages of a few months to 9/10 years. Processes that occur in normally developing children, which, when disrupted, may lead to the formation of alter personalities. These processes include children's normal susceptibility to dissociation, their rich imagination and fantasy, and behavioral states of consciousness.

Children's natural susceptibility to dissociation has an adaptive and defensive role. Dissociation becomes dangerous when it exceeds the limits of normal intensity and frequency. Children engage in this process more easily than adults. If the mechanism is disturbed by repeated abuse in the sensitivity period, the child may develop alter personalities. The task of dissociation is to remove traumatic events from the child's consciousness, to push away dreadful memories and transform them into a thought that "this is not happening to me but to someone else", and to induce analgesia to the physical pain inflicted on the maltreated child.

Imagination and fantasy allow children to project their own personality onto objects and situations [1]. It has been suggested that this may contribute to the blurring of the boundaries between reality and fantasy and the emergence of alter personalities in DID $[1,7,10]$. Another factor promoting the formation of alters may be the fact that children endow their plush toys or dolls with life and personality traits. Another common phenomenon in children is having an imaginary friend. Many adult patients claim that imaginary companions were models for their alter personalities. What is more, alters themselves often admit that they had been created as imaginary friends and later acquired their own lives as a result of trauma [1]. In a study of 12 criminals, as many as ten admitted to having had an imaginary friend in their early years [13].

The construct of behavioral states of consciousness assumes that people are born as potential multiple personalities, and it is only in the course of normal development that these personalities consolidate and integrate into a single Self. Research shows that the behavior of newborns is composed of separate behavioral states, manifesting themselves, among others, through different motor activities, eye movements, facial expressions or skin color. This assumption shows that some of children's most important developmental tasks are to consolidate the Self, work out a sense of one's identity, and learn to smoothly transition from one behavioral state to the next.

From a synthesis of these three mechanisms, Marchwicki derives the principle of formation of alter personalities. A person escapes from an experience of intolerable suffering by entering into a dissociative state. A rich imagination allows the person to fill these states with physical and psychological attributes, which become associated with the feelings and bodily sensations caused by the trauma. Each time the person is abused, a given dissociative state acquires new memories, feelings and behaviors, which make up the story of its life. There exists a significant correlation between the number of alters and the number of different ways in which the child was/ is being abused [1]. The dissociative states become more and more structured as imaginary attributes combine with the real qualities of people from the child's home and community [10]. Because people with DID fail to fully develop normal processes that integrate and modify behavioral states, they depend on more primitive coping methods, such as dissociation and fantasy, what results in the formation of new alter personalities $[1,12]$.

\subsection{The attachment model}

The attachment theory highlights the fact of having a parent or a guardian who, by definition, is responsible for survival of the child, but simultaneously becomes his/her abuser. This model derives from the object relations theory, according to which, in early childhood, people form various representations of themselves and the object (the primary carer, usually a mother) and relate them to one another by appropriate emotions. If one or both carers is/are abusive, the child has to build powerful defensive reactions to maintain the attachment necessary for his/her mental and physical survival. To do this, the child often uses numerous methods, such idealization, dissociation, devaluation, splitting, or internalization of the object, paradoxically identifying himself/herself with the aggressor. In idealizing their care-givers, patients maintain their attachment to them. At the same time, 
they split off negative emotions and memories from the Self, in effect producing an image of themselves that they believe to be ideal. In devaluation, the reverse process takes place: the child shifts the aggressor's blame onto himself/herself, turning the abuser into an ideal object to which he/she can attach himself/herself. Identification with the aggressor, in turn, means that the victim takes over the abuser's power at a moment of powerlessness, thus protecting their own Self. Research shows that this defensive mechanism is used by people who have suffered severe sexual abuse in the childhood. By splitting, the child produces a good and bad representation of himself/ herself and a good and bad representation of the abuser. The victim uses dissociation to remove traumatic memories from his/her consciousness. Owing to all these processes, the child forms an ideal picture of the caregiver, to which he/she can get attached. The bad traits and memories of the abusive parent are swept away from memory, eventually leading to the formation of new alters which allow the child to cope in extreme conditions [9].

Figure 1. DID as a wide range of defense mechanisms against childhood trauma

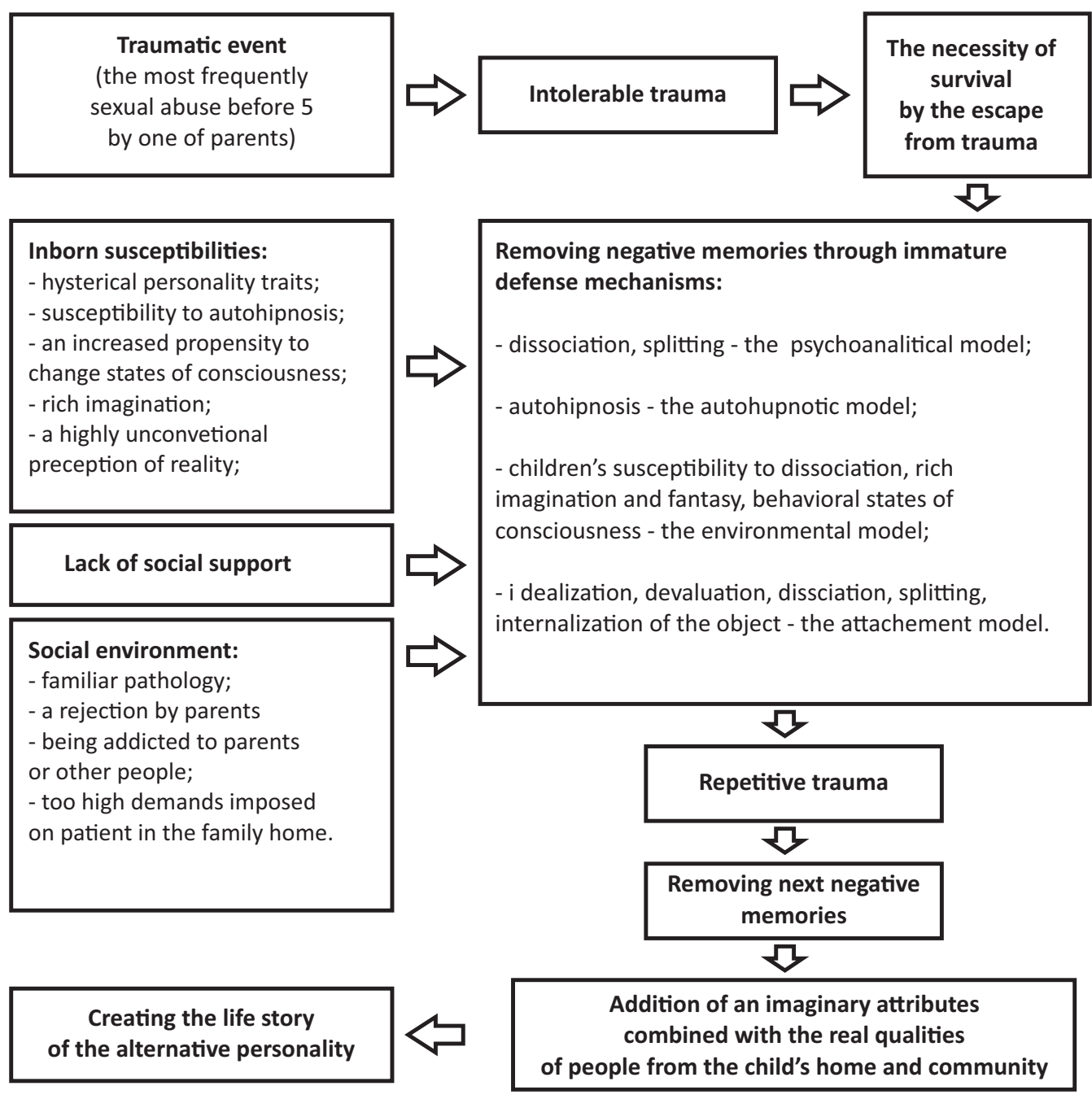

\section{Results and discussion - DID as a response to childhood trauma}

The literature data show that multiple personality disorder is probably a broad variant of the child's defense mechanisms against extreme, traumatic events from childhood, which they try to cope with by creating alter personalities [1-3, 9-14]. This is implied by all the models of DID formation discussed above. Children, between the ages of a few months and 9/10, have no fully created personality nor defense mechanisms and because of that, they can create the alters with more facility than adults [1,9]. Formerly, it was believed that DID affected only adults; now, it is claimed that the disorder can be diagnosed in children as young as three or four years old. Most commonly, however, the diagnosis is made between the ages of 25 and 35, although the first symptoms probably appear five to ten years before the disease is recognized [1].

More often than not, the host is the least disturbed personality. Abused children create other representations of the Self to be able to rid themselves of suffering, a process that is necessary for them to survive and further 
develop mentally and physically $[3,9,14]$. An example that confirms this hypothesis is the case a five-year-old Shari who was raped multiple times by a group of teenagers from the neighborhood. Wanting to protect some part of herself from suffering, she created alter personalities that allowed her to survive [3].

From this perspective, the disorder has an adaptive character, as it makes it easier for the patient to forget the traumatic event. Each of the newly emerging alters stands in contrast to the original personality, which is unable to deal with the trauma. Creating a stronger figure within oneself allows the patient to relieve the suffering and survive events that would be unbearable under normal circumstances [3]. Loewenstein claims that patients with amnesia of the first nine to ten years of their lives most likely suffer from DID [6], what may be due to the fact that these memories have been passed on to one of the alters to protect the original personality from trauma [3]. Many DID patients can reduce or totally suppress their

\section{Wstęp}

Dysocjacyjne zaburzenie osobowości ze względu na swój wyjątkowy charakter i trudności w identyfikacji jest rzadko diagnozowane w Polsce. Zaburzenie to ma swoje korzenie w szczególnie traumatycznych, powtarzalnych zdarzeniach z dzieciństwa, a nie jak zespół stresu pourazowego (PTSD) w tragicznych doświadczeniach w późniejszym okresie życia. Ma to kluczowe znaczenie, ponieważ dziecko nie ma wykształconych odpowiednich mechanizmów obronnych, które pozwolą mu poradzić sobie w tak ekstremalnych warunkach. Wykorzystują one zatem swoją wyobraźnię, fantazję dziecięcą, dysocjację i rozszczepienie, aby zapewnić sobie przetrwanie.

\section{Cel pracy}

Niniejsza praca jest przeglądem dostępnej literatury na temat dysocjacyjnego zaburzenia osobowości jako szerokiego mechanizmu obronnego wśród dzieci z przebytą traumą. Ponadto, tekst ma za zadanie zwrócić uwagę środowiska naukowego na tą jednostkę chorobową oraz rozpocząć dyskusję i polskie badania na ten temat.

\section{Materiały i Metoda}

W celu przeprowadzenia metaanalizy na ten temat wykorzystano dostępne artykuły z bazy danych PubMed, Google Scholar oraz Polskiej Bibliografii Lekarskiej pod hasłami: osobowość mnoga, dysocjacyjne zaburzenie osobowości, dysocjacyjne zaburzenie osobowości a dzieci w przedziale czasowym od 1960 do 2018 roku.

Dla jak najlepszego ukazania charakterystyki tego zagadnienia, artykuł podzielono na następujące podrozdziały: sensibility to pain. This ability manifests itself for the first time during the traumatic event. In addition, they are often able to block all feelings, especially painful ones, what shows that DID can be a defense mechanism against extremely traumatic events from childhood (Fig. 1.) [6].

\section{Conclusions and recommendations.}

In Poland there is a huge gap of review papers, but the most original papers about Dissociative Identity Disorder. There is a need to conduct Polish researches, what could increase knowledge about DID, help to understand the essence of this disorder, allow to diagnose and treat it easier and resolve doubts many of western scholars connected with controversies around an existence of multiple personality. Better understanding of DID could explicate functions of human brain, its ways to cope with extreme situations and explain how much and by what systems of the brain can influence somatic functions of an organism.

1. Dysocjacyjne zaburzenie osobowości - ogólna charakterystyka.

2. Teorie powstawania:

2.1. Model psychoanalityczny;

2.2. Model autohipnotyczny;

2.3. Model ewolucyjny;

2.4. Model przywiązania się;

3. Wyniki i dyskusja - DID jako odpowiedź na traumę z dzieciństwa.

4. Konkluzje i rekomendacje.

\section{Dysocjacyjne zaburzenie osobowości - ogólna charakterystyka.}

Dysocjacyjne zaburzenie osobowości zwane też osobowością mnogą lub wieloraką (ang. Dissociative Identity Disorder, DID) dotyczy osób, u których jednocześnie funkcjonują co najmniej 2 lub więcej osobowości, odznaczające się samodzielnym bytowaniem i pełną kontrolą nad zachowaniem się jednostki [13]. Według ICD-10 osobowość mnoga klasyfikowana jest jako inne zaburzenia dysocjacyjne (konwersyjne) -F44.8 [4]. DSM-V zalicza osobowość mnogą do zaburzeń dysocjacyjnych, definiowaną jako obecność dwóch lub więcej odrębnych stanów osobowości lub doświadczenie opętania z nawracającymi epizodami amnezji, niewytłumaczalnymi zwykłym zapominaniem [5]. DID po raz pierwszy jako osobna jednostka chorobowa została ujęta w DSM-III w 1980 roku w części dotyczącej zaburzeń dysocjacyjnych [2].

Częstotliwość jej występowania u dorosłych w Stanach Zjednoczonych określa się na 1,5\% [5], w Kanadzie od 0,5\% do $2 \%$. W Polsce niestety nie ma dostępnych danych na ten temat [2]. Ilość osobowości 
z reguły oscyluje pomiędzy 3 a 5 albo poniżej 10, ale opisywane są przypadki o 25-30 różnych osobowościach, z czego kobiety średnio posiadają 15, mężczyźni 8 odrębnych osobowości alternatywnych [1,2]. Zaburzenie dotyczy od 3 do 9 razy częściej kobiet niż mężczyzn [2]. Typową dysocjacyjnie zaburzoną osobą jest kobieta, w wieku od dwudziestu do czterdziestu lat, z wykorzystywaniem seksualnym, kazirodztwem lub innym traumatycznym przeżyciem do 5 roku życia w wywiadzie. Pacjent może mieć skłonność do nadmiernej sugestywności, reakcji regresywnych i ucieczkowych $[1,2]$.

U pacjenta z DID występuje kilka kategorii osobowościowych: osobowość pierwotna (original personality), występująca od urodzenia, osobowość alternatywna (alter personality), osobowość fragmentaryczna (fragment personality), prezentująca pojedynczy stan emocjonalny w zależności od danej sytuacji oraz osobowość dominująca, czyli tzw. gospodarz (host personality). Osobowość pierwotna z reguły nie wie o istnieniu pozostałych osobowości, chociaż one są jej świadome i nierzadko wiedzą też o obecności innych osobowości. Najczęściej zdarza się tak, że gospodarz jest najmniej zaburzoną osobowością. Jednak może być też tak, że któreś alter ego lepiej sobie radzi i stara się pomóc osobowości dominującej w danej sytuacji, pojawiając się w momencie kiedy jest najbardziej potrzebne. Stosunek emocjonalny osobowości do siebie, zależy od tego jaką rolę odgrywają poszczególne kategorie osobowościowe [3].

Szczególnie ciekawym elementem tego zaburzenia jest przechodzenie z jednej osobowości w drugą, czyli tzw. przełączanie (switching), zachodzące w sposób łagodny, ciężki do wykrycia, szczególnie jeśli pacjent ukrywa zaburzenie. Zmiana osobowości nie przekracza zwykle 5 minut. Towarzyszy temu szybkie mruganie lub przewrócenie oczami z następującym pustym, nieobecnym wzrokiem. Zmienia się akcja serca i szybkość oddechu oraz postura ciała, mimika twarzy i ton głosu. Osoba może zgłaszać m.in. inne pochodzenie etniczne, religijne, płeć, wiek, nastrój, afekt, zainteresowania, przyzwyczajenia, umiejętności i poziom aktywności [6]. Oto relacja jednej z pacjentek: „Kładę się, choć potrafię to również zrobić siedząc. Skupiam się z całej siły, oczyszczam umysł, zamykam dostęp wszelkim informacjom, po czym wyrażam życzenie, by dana osoba się pojawiła. Nie jestem jednak świadoma tego, co robię." [3].

Osoby z dysocjacyjnym zaburzeniem osobowości wykazują bardzo zróżnicowaną i bogatą symptomatologię psychosomatyczną. Objawy rozciągają się od zwykłych bólów i zawrotów głowy poprzez zmianę charakteru pisma, aż na próbach samobójczych i niepamięci różnych okresów życia, kończąc. Modyfikacje dotyczą również zapisów EKG poszczególnych osobowości, profili hormonalnych, przepływu krwi w naczyniach mózgowych, odczuwaniu bólu czy przebiegu cyklu miesiączkowego. Opisano przypadek pacjentki, która miała miesiączkę przez cały miesiąc, ponieważ jej osobowości miały różne terminy krwawienia [2]. Najpowszechniejsze objawy psychopatologiczne zostały przedstawione w tabeli 1.

Tabela 1. Najczęstsze objawy psychopatologiczne w DID

\begin{tabular}{|l|l|}
\hline Objawy & Liczba pacjentów \\
\hline Istnienie „wewnątrz innej osoby” & 92 \\
\hline Głosy mówiq̨ce & 89 \\
\hline Głosy pochodzące z wewnątrz & 84 \\
\hline Inna osoba bierze nad nim kontrolę & 83 \\
\hline Niepamięć okresu dzieciństwa & 83 \\
\hline Odnoszenie się do siebie samego jako „my” albo „nas” & 75 \\
\hline Osoba „wewnątrz” ma inne nazwisko & 72 \\
\hline Niepamięć pewnych okresów & 69 \\
\hline Wspominanie „scen” z przeszłości & 68 \\
\hline Opowiadanie, przez innych, o zapomnianych wydarzeniach z jego życia & 64 \\
\hline Poczucie nierealności & 58 \\
\hline Znają go „obcy” dla niego ludzie & 45 \\
\hline Wiadomości o jego zaginięciu & 43 \\
\hline Znalezienie się po okresie niepamięci w nieznanym („obcym”) miejscu & 37 \\
\hline Nie można wytłumaczyć pochodzenia części posiadanych przez niego przedmiotów & 32 \\
\hline Ma różne charaktery pisma ręcznego & 28 \\
\hline
\end{tabular}


Diagnostyka zaburzenia opiera się o standaryzowany wywiad: Structured Clinical Interview for DSM-IV Dissociative Disorders-Revised (SCID-D-R) oraz skale: Dissociative Experience Scale (DES), Dissociative Disorders Interview Schedule (DDIS), Somatoform Dissociation Questionnaire (SDQ-20), Childhood Trauma Questionnaire (CTQ) [2,3,7].

Dysocjacyjne zaburzenie osobowości jest na tyle frapującym zaburzeniem, że doczekało się ono licznych odnośników w kulturze. Książka „Sybil” oraz film pod tym samym tytułem opowiadają historię pacjentki z 16 osobowościami. Pozycja ta znalazła się na liście bestsellerów. Innym przykładem może być film o tytule „Trzy oblicza Ewy” oparty na prawdziwych wydarzeniach, dotyczący kobiety przełączającej się pomiędzy trzema różnymi osobowościami [2].

\section{Teorie powstawania.}

Etiologia dysocjacyjnego zaburzenia osobowości nadal nie jest jasna. Przypuszcza się, że jest to synteza wielu czynników, wśród których można wymienić m.in. wrodzone predyspozycje, brak wsparcia z zewnątrz, środowisko, na które składa się szczególnie rodzina oraz traumatyzujące zdarzenia $\mathrm{z}$ dzieciństwa [2]. Obecność traumatycznych wydarzeń w dzieciństwie relacjonuje 97\% pacjentów z osobowością mnogą, w tym $85 \%$ stanowi wykorzystywanie seksualne. Jest to najczęściej przytaczany rodzaj nadużycia [1,6]. Osoby te doświadczały ciężkiej, powtarzalnej traumy z rąk rodziców [8]. Inne zdarzenia pozostawiające piętno na pacjentach to, np. kazirodztwo (68\%), fizyczne znęcanie się $(75 \%)$, ekstremalne zaniedbania ze strony opiekunów (60\%), śmierć lub obecność przy śmierci bliskiej osoby (40\%). Zwykle zdarzenia te miały miejsce przed ukończeniem 5 roku życia [1,2]. Nierzadkie są również opisy bardziej wymyślnych sposobów znęcania się nad dziećmi. Oprócz różnego rodzaju praktyk seksualnych, osoby te były maltretowane fizycznie poprzez bicie, kopanie, przypalanie żelazkiem lub zapałkami, stosowanie lewatyw, więzienie w piwnicy, w szafie, w bagażniku samochodu. Istnieje opis przypadku, w którym osoba jako dziecko została zakopana żywcem w ziemi, przy czym sprawca pozostawił nad jej twarzą rurę do oddychania, przez którą oddawał na nią mocz. W szerokim wachlarzu sposobów znęcania się nad dziećmi z DID występują także różne formy traumy psychicznej, np. stałe oczernianie, upokarzanie, zmuszanie do oglądania wykorzystywania seksualnego rodzeństwa. Wszystkie te przypadki łączy ze sobą szczególna drastyczność i powtarzalność nadużyć. Większość badaczy i klinicystów zajmujących się tym zaburzeniem uważa, że traumatyczne zdarzenia z wczesnego dzieciństwa są źródłem trzech modeli powstawania osobowości mnogiej. Należą do nich:
2.1. model psychoanalityczny;

2.2. model autohipnotyczny;

2.3. model ewolucyjny [1]

$\mathrm{Na}$ uwagę zasługuje również śmiała hipoteza Bowlby'ego:

2.4. model przywiązania się [9];

Wszystkie te modele tłumaczą osobowość mnogą jako ekstremalny sposób radzenia sobie dzieci z traumą nie do zniesienia, od której nie mogą one uciec i przed, którą nie mogą się bronić z racji swojej niedojrzałości fizycznej i psychicznej.

\subsection{Model psychoanalityczny}

Teoria ta zakłada, że osobowości alternatywne powstają nie przez zdarzenie traumatyczne jako takie, ale wskutek mechanizmów obronnych, które mają za zadanie chronić jednostkę przed treściami niebezpiecznymi [1]. Model ten nawiązuje do opinii Z. Freuda przedstawionej przez niego w Studiach nad Histerią [10]. W DID najważniejszą rolę pełnią dwa mechanizmy obronne: rozszczepienie i dysocjacja.

Rozszczepienie to naturalny proces psychiczny, zachodzący głównie u niemowląt, w celu oddzielenia od siebie dobra i zła. Kiedy dziecko stale jest poddawane traumatycznym przeżyciom zaczyna nadużywać tego mechanizmu nawet w sytuacjach niezagrażających, co pozwala mu wytworzyć dwa niesprowadzalne do siebie światy. To stwarza kolejne osobowości alternatywne, stanowiące ochronę przed traumą [1,9].

Dysocjacja to kolejny prymitywny mechanizm obronny, oddzielający określone myśli, wspomnienia lub afekty od reszty osobowości, powodując ich autonomiczne funkcjonowanie. Dysocjacją kieruje proces pierwotny, który działając na oddalone z pola świadomości myśli i uczucia, poddaje je działaniu mechanizmów obronnych, charakterystycznych dla procesu pierwotnego: przesunięcia, kondensacji i symbolizacji. Zgodnie z tym co twierdził Freud, proces pierwotny, w przeciwieństwie do procesu wtórnego, jest związany z brakiem związków przyczynowo-skutkowych, brakiem przeciwieństw i czasu oraz współistnienia sprzeczności. Ma on za zadanie jak najszybsze rozładowanie napięcia poprzez wytworzenie wyobrażeń obiektu zaspokajającego potrzebę. Brak tu również rozróżnienia między fantazją a rzeczywistością, co zdaje się wyjaśniać, dlaczego osobowości alternatywne nie odczuwają sprzeczności w związku z posiadaniem innej płci, rasy lub wieku niż osobowość pierwotna [1].

Model psychoanalityczny sugeruje zatem, że do powstania DID potrzebne są dwie komponenty tj. zarówno trauma jak i fantazja. Teoria ta jednak nie jest doskonała, 
nie wyjaśnia bowiem wszystkich objawów klinicznych [10]. Co więcej, twierdzi się, że nie każda osoba, która potrafi dysocjować wykształca alternatywne osobowości [11], chociaż z kolei pacjenci cierpiący na DID mają istotnie zwiększoną zdolność do dysocjacji, co sugeruje, że jest to cecha predysponująca do tego zaburzenia [7].

\subsection{Model autohipnotyczny}

Model ten, podobnie jak poprzedni, za podstawę istnienia przyjmuje ucieczkę od traumatyzującego wydarzenia, ale poprzez mechanizm autohipnozy, który następnie staje się sposobem na obronę przed stresującymi sytuacjami w życiu $[1,9,10,12]$.

Dowiedziono, że pacjenci z DID mają wzmożoną zdolność do hipnozy, chociaż sami często nie zdają sobie z tego sprawy [6]. Autohipnoza wyjaśnia możliwość powstawania amnezji, innych osobowości i posiadania rzeczy nierozpoznawanych jako swoje [10]. Bliss posuwa się nawet do stwierdzenia, że osobowość mnoga jest formą autohipnozy, a inne jej objawy jak: zmiany oddychania, nieregularne miesiączki czy palpitacje są manifestacjami lęku [12].

Model ten przyjmuje założenie, że hipnoza to kontrolowana dysocjacja, a dysocjacja z kolei jest formą autohipnozy. Niestety, z czasem przy powtarzających się traumach proces ten staje się rozwiązaniem na doświadczane przykrości. Często stosowany, ingeruje coraz bardziej w pamięć, poczucie własnego Ja i normalną zdolność do radzenia sobie $\mathrm{w}$ rzeczywistym świecie. Stopień zmian może się rozciągać od krótkich amnezji, aż po wytworzenie się osobowości alternatywnych, mogących przejmować kontrolę nad ciałem pacjenta.

Na korzyść tego modelu przemawia zwiększona zdolność pacjentów do hipnozy, możliwość wyjaśnienia wielu objawów zaburzenia przez pryzmat autohipnozy oraz to, że jest to pomocna metoda zarówno w diagnostyce jak i w leczeniu osobowości wielorakiej.

Krytyka tej teorii odnosi się do utożsamiania podatności na hipnozę z podatnością do dysocjacji. Część badań wskazuje, że nie są to procesy synonimiczne, ponieważ niektóre osoby o dużej podatności do dysocjacji są też podatne na hipnozę, ale nie wszystkie osoby podatne na hipnozę są również zdolne do dysocjacji [1].

\subsection{Model rozwojowy}

Z badań wynika, że osoby cierpiące na DID mają pewien okres szczególnej wrażliwości, w którym traumatyczne wydarzenia mogą doprowadzić do wytworzenia się osobowości mnogiej. Jest to wiek między kilkoma miesiącami a 9/10 rokiem życia. Wskutek zaburzenia procesów występujących u normalnie rozwijających się dzieci może dojść do powstania osobowości alternatywnych. Procesami tymi są: normalna podatność dzieci do dysocjacji, wyobraźnia i fantazja dziecięca oraz behawioralne stany świadomości.

Normalna podatność dzieci do dysocjacji pełni rolę przystosowawczą i obronną. Dysocjacja staje się groźna w momencie, gdy przekracza granicę zbyt dużej intensywności i częstotliwości. Dzieci wchodzą w ten proces z większą łatwością niż dorośli. Przy zaburzeniu tego mechanizmu poprzez powtarzające się znęcanie w okresie wrażliwości, następuje wytworzenie się osobowości alternatywnych. Dysocjacja ma za zadanie usunąć traumatyczne zdarzenia ze świadomości dziecka, oddalić wstrząsające wspomnienia i przekształcić je w myśl, że to nie zdarza się mnie tylko komuś innemu oraz spowodować analgezję na ból fizyczny zadawany mu podczas znęcania się.

Wyobraźnia i fantazja dziecięca sprawiają, że dzieci mogą projektować własną osobowość na przedmioty i sytuacje [1]. Sugeruje się więc, że może to być przyczynkiem do zatarcia się granic między rzeczywistością a fantazją i powstania osobowości alternatywnych $[1,7,10]$. Sprzyjające ku temu może być także nadawanie pluszakom czy lalkom, życia oraz cech osobowości. Również powszechnym zjawiskiem u dzieci jest posiadanie wymyślonego przyjaciela. Wielu dorosłych pacjentów twierdzi, że pierwowzorem ich osobowości alternatywnych byli wyimaginowani kompani. Co więcej, same osobowości alternatywne przyznają, że powstały jako wymyśleni przyjaciele a potem $\mathrm{w}$ wyniku traumy uzyskały własne życie [1]. W badaniu na 12 przestępcach cierpiących na DID, aż 10 przyznało się do posiadania wyimaginowanego przyjaciela we wczesnych latach życia [13].

Behawioralne stany świadomości zakładają, że ludzie rodzą się jako potencjalne osobowości mnogie i tylko w trakcie prawidłowego rozwoju dochodzi do ich konsolidacji i integracji w jedno Ja. Z badań wynika, że sposób zachowywania się noworodków jest zorganizowany z oddzielnych stanów behawioralnych, objawiających się m.in. poprzez odmienne czynności motoryczne, ruchy oczu, wyraz twarzy czy kolor skóry. Z tego założenia wynika, że jednym z zadań rozwojowych dzieci jest konsolidacja Ja, wypracowanie poczucia własnej tożsamości oraz nauczenie się płynnego przechodzenia między jednym a drugim stanem behawioralnym.

Z syntezy tych trzech mechanizmów Marchwicki wyprowadza zasadę powstawania osobowości alternatywnych. Za pomocą dysocjacji osoba ucieka od doświadczania wielkiego cierpienia poprzez wejście w stan dysocjacyjny. Duża wyobraźnia pozwala jej wypełnić te stany atrybutami fizycznymi i psychologicznymi, które łączą się z uczuciami i doznaniami cielesnymi wywołanymi przez traumę. Za każdym razem podczas 
nadużywania, dany stan dysocjacyjny otrzymuje nowe wspomnienia, uczucia i zachowania, tworząc historię swojego życia. Znamienna jest korelacja między ilością alter ego a liczbą różnych rodzajów wykorzystywania danego dziecka [1]. Stany dysocjacyjne stają się coraz bardziej ustrukturalizowane poprzez kombinację wyimaginowanych cech i prawdziwych cech ludzi z otoczenia dziecka [10]. W konsekwencji braku pełnego rozwoju normalnych procesów integrujących i modulujących stany behawioralne, osoby z DID zależne są od bardziej prymitywnych sposobów radzenia sobie jak dysocjacja i fantazja, co z kolei skutkuje powstawaniem kolejnych osobowości alternatywnych [1,12].

\subsection{Model przywiązania się}

W tej koncepcji jest podkreślony fakt iż, rodzic bądź opiekun, który jest odpowiedzialny za przetrwanie dziecka jednocześnie staje się osobą je wykorzystującą. Model ten wywodzi się $\mathrm{z}$ teorii relacji $\mathrm{z}$ obiektem, polegającej na wytworzeniu we wczesnym dzieciństwie różnych reprezentacji siebie oraz obiektu (tj. głównego opiekuna, z reguły matki) i połączeniu ich między sobą poprzez odpowiednie emocje. Jeśli jedno lub oboje opiekunów jest nadużywające, dziecko musi zbudować potężne reakcje obronne, żeby utrzymać przywiązanie konieczne do psychicznego i fizycznego przetrwania. Aby dokonać tego, dziecko często stosuje wiele metod, np. idealizację, dysocjację, dewaluację, rozszczepienie lub internalizację obiektu, paradoksalnie identyfikując się z agresorem. Pacjent idealizując swojego opiekuna utrzymuje przywiązanie do niego. W sobie samym zaś, dokonuje odszczepienia negatywnych emocji i wspomnień, w efekcie pozostawiając swój wizerunek idealnym $\mathrm{w}$ swoim mniemaniu. $\mathrm{W}$ dewaluacji dzieje się proces odwrotny, dziecko przerzuca winę agresora na siebie, pozostawiając go idealnym obiektem, do którego może się przywiązać. Identyfikacja z agresorem z kolei, powoduje że ofiara przejmuje władzę od osoby nadużywającej w momencie bezsilności, dzięki temu chroniąc swoje Ja. Badania pokazują, że ten sposób obrony stosują osoby po ciężkim wykorzystywaniu seksualnym w dzieciństwie. Poprzez rozszczepienie, dziecko wytwarza dobrą i złą reprezentację siebie samego oraz dobrą i złą reprezentację osoby nadużywającej. Dysocjacji używa do usunięcia ze swojej świadomości traumatycznych wspomnień. Dzięki tym wszystkim procesom powstaje idealny obraz opiekuna, do którego dziecko może się przywiązać. Złe cechy i wspomnienia odnośnie nadużywającego rodzica zostają wyparte $\mathrm{z}$ pamięci tworząc $\mathrm{w}$ końcu kolejne osobowości dziecka, pozwalające mu radzić sobie w ekstremalnych warunkach [9].

\section{Wyniki i dyskusja - DID jako odpowiedź na traumę z dzieciństwa.}

Z zebranych danych wynika, że osobowość mnoga jest prawdopodobnie szerokim wariantem mechanizmów obronnych dziecka przed ekstremalnymi, traumatycznymi zdarzeniami z dzieciństwa, z którymi radzi sobie poprzez wytworzenie alternatywnych osobowości $[1-3,9-12,14]$. Wskazują na to wszystkie przytoczone modele powstawania DID. Jako, że dzieci w wieku od kilku miesięcy do 9/10 roku życia, nie posiadają jeszcze w pełni wytworzonej osobowości ani poprawnych mechanizmów obronnych dużo łatwiej wytwarzają osobowości alternatywne w porównaniu do ludzi dorosłych [1,9]. Dawniej uważano, że DID dotyczy jedynie osób dorosłych, obecnie twierdzi się, że zaburzenie może być diagnozowane nawet u 3-4-letnich dzieci. Przeciętnie jednak rozpoznanie stawiane jest między 25 a 35 rokiem życia [1], chociaż pierwsze symptomy występują prawdopodobnie od 5 do 10 lat wcześniej.

Najczęściej jest tak, że gospodarz jest najmniej zaburzoną osobowością. Dziecko tworzy inne reprezentacje siebie, aby móc pozbyć się cierpienia, co jest niezbędne do przetrwania i dalszego rozwoju psychicznego jak i fizycznego $[3,9,14]$. Na potwierdzenie tej hipotezy można przytoczyć opis przypadku pięcioletniej Shari, która została wielokrotnie zgwałcona przez grupę nastolatków z sąsiedztwa. Chcąc uchronić jakąś część siebie od cierpienia, wykreowała ona osobowości alternatywne, które umożliwiły jej przetrwanie [3].

Trauma z dzieciństwa i mechanizmy obronne powodują, że w ten sposób możemy mówić o adaptacyjnej stronie tego zaburzenia, ułatwiającej zapomnienie traumatycznego zdarzenia. Każda z nowo pojawiających się osobowości alternatywnych jest kontrastem dla osobowości pierwotnej, nieradzącej sobie $\mathrm{z}$ traumą. Stworzenie silniejszej postaci wewnątrz siebie przynosi ulgę w cierpieniu i pozwala przetrwać zdarzenia, które normalnie są nie do zniesienia [3]. Loewenstein twierdzi, że pacjenci z amnezją dla pierwszych 9 do 10 lat życia z wielkim prawdopodobieństwem cierpią na DID [6], co może się wiązać z tym, że wspomnienia te zostały przekazane którejś z innych osobowości, chroniąc w ten sposób osobowość pierwotną przed traumą [3]. Wielu pacjentów z tym zaburzeniem ma zdolność do zmniejszania lub całkowitego braku czucia bólu, która pojawiła się po raz pierwszy podczas traumatycznego wydarzenia. Ponadto, często potrafią oni blokować wszystkie uczucia, a w szczególności te bolesne co pokazuje, że DID może być mechanizmem obronnym, chroniącym przed skrajnie traumatycznymi zdarzeniami z dzieciństwa (ryc. 1) [6]. 
Rycina 1. DID jako mechanizm obronny przed trauma z dzieciństwa

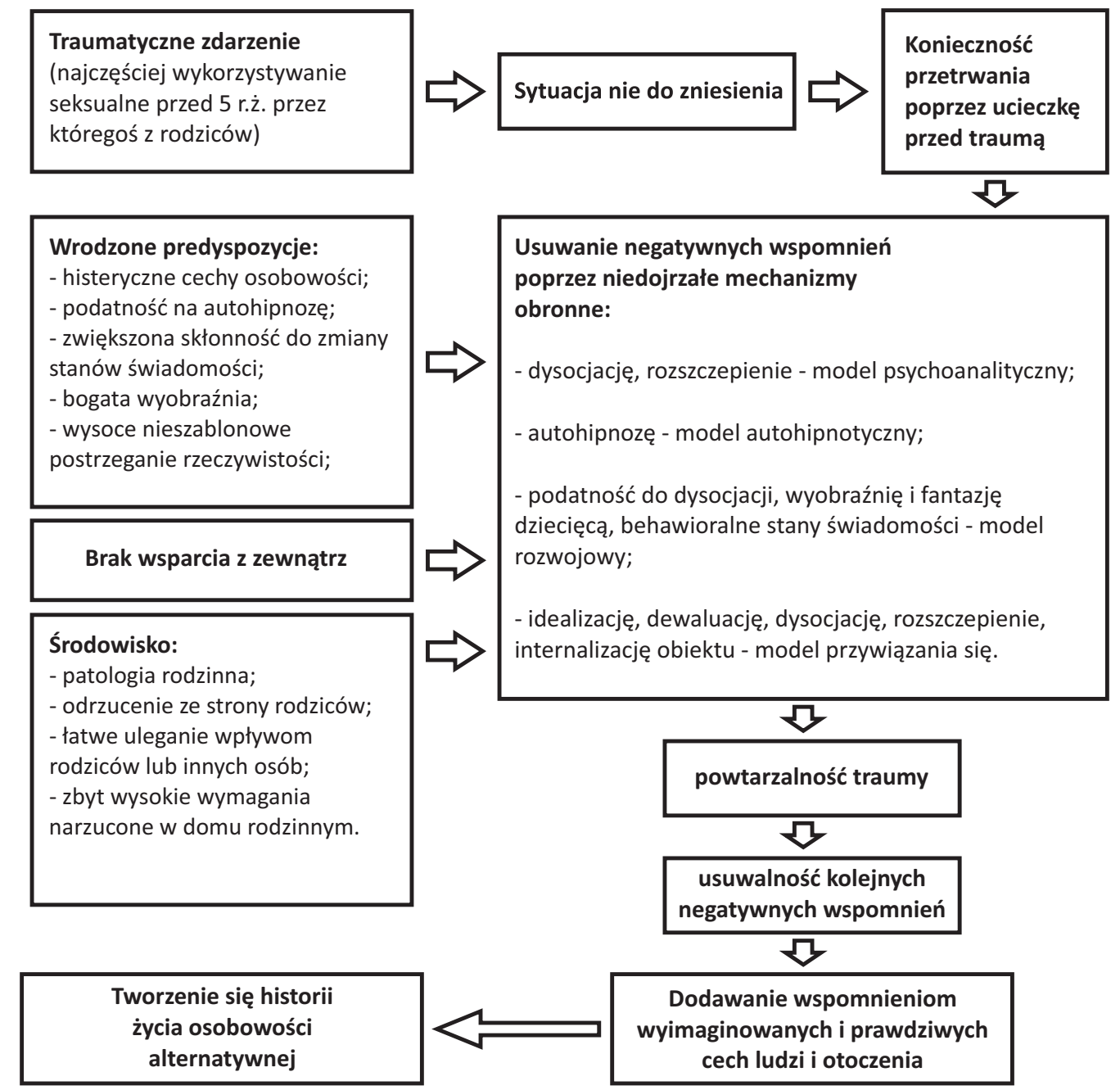

\section{Konkluzje i rekomendacje.}

W Polsce występuje ogromny deficyt prac przeglądowych, ale przede wszystkim oryginalnych prac badawczych, na temat dysocjacyjnego zaburzenia osobowości. Warto byłoby przeprowadzić własne, polskie badania dotyczące tego zaburzenia, co przysporzyłoby więcej wiedzy odnośnie DID, pomogło bardziej zrozumieć istotę tego zaburzenia, pozwoliłoby na lepsze rozpoznawanie i leczenie oraz być może rozwiałoby wątpliwości co do istnienia osobowości mnogiej, gdyż jest to poddawane pod wątpliwość przez wielu zachodnich badaczy. Lepsze zrozumienie DID przybliżyłoby możliwość dokładniejszego poznania funkcjonowania ludzkiego mózgu, jego sposobów radzenia sobie w ekstremalnych sytuacjach oraz dotarcia do wiedzy na temat tego jak bardzo i poprzez jakie drogi mózg potrafi wpływać na funkcjonowanie somatyczne organizmu.

\section{Conflict of interest}

The author has declared no conflict of interest.

\section{References:}

1. Marchwicki P. Osobowość wieloraka: kryteria diagnostyczne modele etiologiczne. Seminare. Poszukiwania naukowe. 2004; 20: 357-368.

2. Pobocha J. Osobowość mnoga: diagnostyka, orzecznictwo sądowo-psychiatryczne. Postępy Psychiatrii i Neurologii. 2000; 9(2): 233-242.

3. Stankiewicz S, Golczyńska M. Spór o osobowość mnogą: zagadnienie teoretyczne, czy praktyczne? Psychiatria Polska, 2006; XL(2): 233-243.

4. Międzynarodowa Statystyczna Klasyfikacja Chorób i Problemów Zdrowotnych-X Rewizja. Centrum Systemów Informacyjnych Ochrony Zdrowia. Warszawa: 2008.

5. Diagnostic and Statistical Manual of Mental Disorders. Fifth Edition. DSM-5. Washington DC, London, England; American Psychiatric Publishing: 2013.

6. Loewenstein R.L. An office mental status examination for chronic complex dissociative symptoms and multiple personality disorder. Psychiatric Clinics of North America. 1991; 14(3): 567-602.

7. Scorppo J, Drob S., Weinberg J., Eagle P. Identifying dissociative identity disorder: A self-report and projective study. Journal of Abnormal Psychology. 1998; 107(2): 272-284. 
8. Raaz N, Carlson-Sabelli L, Sabelli HC Psychodrama in The Treatment of Multiple Personality Disorder: A Process-theory Perspective. In: Kluft ES, M.C.A.T., A.D.T.R. (Eds.), Expressive and functional therapies in the treatment of Multiple Personality Disorder., USA; Charles Thomas Publisher: 1992, pp. 169-188.

9. Blizard RA The origins of Dissociative Identity Disorder from an object relations and attachment theory perspective. International Society for the Study of Dissociation, 1997.

10. Young $\mathrm{WC}$, Observations on fantasy in the formation of multiple personality disorder. Diossociation, 1988; 1(3): 13-20.

11. Braun BG Multiple Personality Disorder: An Overview. The American Journal of Occupational Therapy. 1990; 44(11): 971976.

12. Coons PM Psychophysiologic Aspects of Multiple Personality Disorder. A Review. Dissociation, 1988; 1(1): 47-53.

13. Otnow-Lewis D, Yeager CA, Swica Y, Pincus JH, Lewis M. Objective Documentation of Child Abuse and Dissociation in 12 Murderers with Dissociative Identity Disorder. American Journal of Psychiatry, 1997; 154(12): 1703-1710.

14. Baldwin LC Child Abuse as an Antecedent of Multiple Personality Disorder. The American Journal of Occupational Therapy. 1990; 44(11): 978-983.

\section{Corresponding author}

Ewelina Soroka

II Department of Psychiatry and Psychiatric Rehabilitation, Medical University of Lublin e-mail: dziwota.e@gmail.com

Otrzymano: 13.03.2019

Zrecenzowano:20.06.2019

Przyjęto do druku:26.06.2019 